\title{
Pengaruh Pembelajaran Pencapaian Konsep Terhadap Kemampuan Bertanya dan Kemampuan Pemahaman Konsep Matematika Pada Siswa Kelas VII SMP Negeri 2 Pondok Kubang
}

\author{
Ikronudi \\ Guru SMP N 2 Pondok Kubang Bengkulu Tengah \\ ikronudi_unib@yahoo.co.id
}

\begin{abstract}
ABSTRAK
Tujuan penelitian ini adalah Untuk mengetahui pengaruh model pembelajaran pencapaian konsep terhadap kemampuan bertanya dan terhadap kemampuan pemahaman konsep; dan Untuk mengetahui kemampuan bertanya siswa dan kemampuan pemahaman konsep yang diajarkan dengan model pembelajaran pencapaian konsep lebih tinggi dibandingkan siswa yang diajarkan dengan pembelajaran konvensional. Untuk mencapai tujuan penelitian ini, maka rancangan penelitian ini adalah desain pretes-postes dua kelompok, dengan populasi seluruh siswa kelas VII SMP Negeri 2 Pondok Kubang tahun ajaran 2013/2014 yang terdiri dari 3 kelas. Sedangkan sampel dalam penelitian ini dipilih dua kelas secara acak, satu kelas VII1 sebagai kelas eksperimen dan kelas VII2 sebagai kelas kontrol. Data yang dikumpulkan dari hasil penelitian ini dianalisi dengan menggunakan dua teknik analisa data, yaitu analisis statistik deskriptif dan analisis statistik inferensial. Berdasarkan hasil analisis deskriptif dan inferensial, maka diperoleh beberapa kesimpulan sebagai berikut: 1) Ada pengaruh model pembelajaran pencapaian konsep terhadap kemampuan bertanya; 2) Ada pengaruh model pembelajaran pencapaian konsep terhadap kemampuan pemahaman konsep; 3) kemampuan bertanya siswa yang diajarkan dengan model pembelajaran pencapaian konsep lebih tinggi dibandingkan siswa yang diajarkan dengan pembelajaran konvensional; 4) kemampuan pemahaman konsep siswa yang diajarkan dengan model pembelajaran pencapaian konsep lebih tinggi dibandingkan siswa yang diajarkan dengan pembelajaran konvensional.
\end{abstract}

Kata Kunci: Model pembelajaran pencapaian konsep, kemampuan bertanya dan kemampuan pemahaman konsep.

\section{Pendahuluan}

Matematika sangatlah penting untuk dipelajari, maka pelajaran matematika perlu ditingkatkan mutu pembelajarannya. Peningkatan itu tidak akan berhasil jika tidak dilaksanakan secara bersama-sama, baik pihak yang terlibat secara langsung maupun pihak yang tidak langsung. Guru dan siswa adalah pihak yang terlibat secara langsung dalam meningkatkan mutu pembelajaran matematika di sekolah. Maka guru dalam proses pembelajaran, bukan sekedar menyampaikan materi saja tetapi juga sebagai fasilitator, pembimbing, dan 
organisator.

Selama ini pembelajaran matematika di sekolah masih bersifat konvensional dimana pembelajaran didominasi oleh guru. Siswa menerima pelajaran matematika secara pasif, hanya menghafal rumus-rumus. Keadaan tersebut menggambarkan bahwa kemampuan pemahaman konsep matematika siswa masih rendah. Dengan kemampuan pemahaman konsep matematika yang rendah siswa akan mengalami kesulitan dalam menyelesaikan soal-soal latihan.

Akibatnya hasil belajar matematika di sekolah masih relatif rendah dan tidak mengalami peningkatan yang berarti. Hal ini dapat dilihat dari hasil penelitian di Indonesia yang menunjukkan bahwa tingkat penguasaan peserta didik dalam matematika pada semua jenjang pendidikan (SD s.d PT) masih sekitar $34 \%$ (Masykur Ag, 2007: 6). Salah satu cara yang dapat dilakukan oleh guru adalah memilih metode pembelajaran matematika yang tepat dan menarik.

Berdasarkan permasalahan di atas, maka penulis mencoba menerapkan suatu model pembelajaran yaitu Model Pembelajaran Pencapaian Konsep. Model pembelajaran pencapaian konsep adalah suatu strategi mengajar bersifat induktif yang dirancang untuk membantu siswa dari semua usia dalam menguatkan pemahaman konsep siswa dan melatih menguji hipotesis (Eggan dan Kauchak, 1996).

Adapun tahapan-tahapan penerapan model pembelajaran pencapaian konsep dalam penelitian ini ada tiga tahapan,yaitu sebagai berikut:

1. Tahap pertama: Penyajian Contoh

1). Guru menyajikan contoh-contoh yang telah dilabeli;

2). Siswa membandingkan sifat-sifat/ciri-ciri dalam contoh dan bukan contoh;

3). Siswa menjelaskan sebuah definisi menurut sifat-sifat/ciri-ciri yang paling esensial;

2. Tahap kedua: Pengujian Pencapaian konsep

1). Siswa mengidentifikasi contoh-contoh tambahan yang tidak dilabeli dengan tanda "Ya" dan "Tidak";

2). Guru menguji hipotesis, menamai konsep, dan menyatakan kembali definisi-definisi menurut sifat-sifat/ ciri-ciri yang paling esensial;

3). Siswa membuat contoh-contoh lain;

3. Tahap ketiga: Analisis Strategi Berpikir

1). Siswa mendeskripsikan pemikiran-pemikiran sendiri;

2). Siswa mendiskusikan peran sifat-sifat dan hipotesis-hipotesis;

3). Siswa mendiskusikan jenis dan ragam hipótesis;

Melalui tahapan-tahapan model pembelajaran pencapaian konsep yang sistematis, dimana siswa diberikan kesempatan lebih banyak untuk berinteraksi antar sesama teman maupun siswa dengan guru, siswa saling bertanya dalam mempelajari konsep. Dan pembelajaran ini melibatkan siswa secara aktif, maka siswa merasa bahwa ia ikut serta dalam pembelajaran matematika tersebut. Sehingga siswa berusaha memahami materi yang sedang dipelajari. Siswapun bersemangat mengajukan pertanyaan-pertanyaan untuk memahami konsep yang sedang dipelajari. Hal ini berarti model pembelajaran pencapaian konsep akan meningkatkan kemampuan bertanya siswa. Begitu juga dengan pemahaman konsep siswa akan meningkat, karena model pembelajaran pencapaian konsep menitik beratkan pada penguatan pemahaman konsep siswa. 
Berdasarkan latar belakang di atas, pertanyaan yang muncul dari peneliti adalah apakah terdapat pengaruh model pembelajaran pencapaian konsep terhadap kemampuan bertanya dan kemampuan pemahaman konsep; apakah kemampuan bertanya dan kemampuan pemahaman konsep siswa yang diajarkan dengan model pembelajaran pencapaian konsep lebih tinggi dari siswa yang diajarkan dengan pembelajaran konvensional. Penelitian ini bertujuan untuk mengetahui pengaruh model pembelajaran pencapaian konsep terhadap kemampuan bertanya dan kemampuan bertanya; dan untuk mengetahui kemampuan bertanya dan kemampuan pemahaman konsep siswa yang diajarkan dengan model pembelajaran pencapaian konsep lebih tinggi dari siswa yang diajarkan dengan pembelajaran konvensional.

\section{Metode Penelitian}

Penelitian ini termasuk jenis penelitian eksperimen semu (quasi experiment). Penelitian eksperimen bertujuan untuk menguji hipotesis dengan rancangan penelitian di mana kedua sampel diberi perlakuan berbeda. Pada sampel pertama kelas X-1 adalah (kelas eksperimen) diberi perlakuan pembelajaran yang dilaksanakan dengan menggunakan pembelajaran pencapaian konsep dan sampel kedua kelas X-2 adalah (kelas kontrol) diberikan pembelajaran yang dilaksanakan secara konvensional.

Instrumen penelitian yaitu meliputi, lembar pengamatan aktivitas siswa, lembar pengamatan aktivitas guru, lembar tes Kemampuan Bertanya siswa, lembar tes kemampuan pemahaman konsep siswa, lembar keterlaksanaan rencana pembelajaran dan angket respon siswa.

Untuk menjawab rumusan masalah dan untuk menguji hipotesis yang diajukan dalam penelitian ini, maka data yang dikumpulkan dari hasil penelitian ini, dianalisis dengan menggunakan dua teknik analisis data, yaitu analisis statistik deskriptif dan analisis statistik inferensial.

\section{Hasil Penelitian dan Pembahasan}

Berdasarkan hasil analisis statistika inferensial data kemampuan bertanya, yaitu sebagai berikut: Model regresi sederhana yang menyatakan hubungan kemampuan awal (pretes) dan hasil belajar (postes) siswa yang diajarkan dengan model pembelajaran pencapaian konsep adalah $\mathrm{Y}=73,78+0,34 \mathrm{X}$. Model regresi sederhana yang menyatakan hubungan kemampuan awal (pretes) dan hasil belajar (postes) siswa yang diajarkan dengan model pembelajaran konvensional adalah $\mathrm{Y}=49,18+$ $0,43 X$.

Dari hasil analisis uji independensi model regresi kemampuan bertanya dengan model pembelajaran pencapaian konsep maupun dengan model konvensional, kedua model regresi tersebut menunjukkan bahwa kemampuan awal (hasil pretes) siswa (X) mempunyai pengaruh yang signifikan terhadap hasil belajar (hasil postes) siswa (Y). Kemampuan awal yang dimiliki oleh siwa merupakan variabel kovariat atau variabel pengganggu yang tidak bisa dikontrol. Karena kemampuan itu sudah ada pada diri siswa yang menjadi objek penelitian. Variabel kovariat tersebut tidak bisa dihilangkan, tetapi dimurnikan dengan menggunakan analisis kovarian atau ANAKOVA.

Selanjutnya hasil analisis linieritas model regresi kemampuan bertanya dengan model pembelajaran pencapaian konsep dan model konvensional, kedua model 
regresi di atas memenuhi model regresi linier. Hubungan kemampuan awal dengan hasil belajar dapat dinyatakan dalam bentuk regresi linier. Hal ini mengidentifikasikan bahwa semakin tinggi kemampuan awal siswa (hasil pretes) akan diikuti semakin tingginya hasil belajar siswa tersebut (hasil postes).

Kemudian Garis regresi kelas eksperimen dan kelas kontrol sejajar, dan konstanta garis regresi untuk kelas eksperimen lebih besar dari konstanta garis regresi untuk kelas kontrol, yaitu 73,78 > 49,19 hal ini menunjukkan ada perbedaan yang signifikan antara dua model regresi kemampuan bertanya. Secara geometris garis regresi untuk kelas eksperimen di atas garis regresi kelas kontrol, yang berarti bahwa kemampuan bertanya kelas eksperimen yang diberi pembelajaran dengan model pembelajaran pencapaian konsep (MPPK) pokok bahasan persamaan kuadrat adalah lebih tinggi dibandingkan dengan kemampuan bertanya kelas kontrol yang diberi pembelajaran matematika konvensional untuk pokok bahasan yang sama.

Berdasarkan hasil analisis statistika inferensial data kemampuan pemahaman konsep, yaitu sebagai berikut: Model regresi sederhana yang menyatakan hubungan kemampuan awal (pretes) dan hasil belajar (postes) siswa yang diajarkan dengan model pembelajaran pencapaian konsep adalah $\mathrm{Y}=75,91+0,30 \mathrm{X}$. Model regresi sederhana yang menyatakan hubungan kemampuan awal (pretes) dan hasil belajar (postes) siswa yang diajarkan dengan model pembelajaran konvensional adalah $\mathrm{Y}=$ $51,73+0,34 X$.

Dari hasil analisis uji independensi model regresi kemampuan pemahaman konsep dengan model pembelajaran pencapaian konsep maupun dengan pembelajaran konvensional kedua model regresi tersebut menunjukkan bahwa kemampuan awal (hasil pretes) siswa (X) mempunyai pengaruh yang signifikan terhadap hasil belajar siswa (Y).

Selanjutnya hasil analisis lineritas model regresi kemampuan pemahaman konsep dengan model pembelajaran pencapaian konsep maupun dengan pembelajaran konvensional, kedua model regresi tersebut memenuhi model regresi linier. Hal ini mengidentifikasikan bahwa semakin tinggi kemampuan awal siswa (hasil pretes) akan diikuti semakin tingginya hasil belajar siswa tersebut (hasil postes).

Kemudian berdasarkan Garis regresi kelas eksperimen dan kelas kontrol sejajar, dan konstanta garis regresi untuk kelas eksperimen lebih besar dari konstanta garis regresi untuk kelas kontrol, yaitu 75,91 > 51,73 hal ini menunjukkan ada perbedaan yang signifikan antara dua model regresi kemampuan pemahaman konsep. Secara geometris garis regresi untuk kelas eksperimen di atas garis regresi kelas kontrol, yang berarti bahwa kemampuan pemahaman konsep kelas eksperimen yang diberi pembelajaran dengan model pembelajaran pencapaian konsep (MPPK) pokok bahasan persamaan kuadrat adalah lebih baik dibandingkan dengan kemampuan pemahaman konsep kelas kontrol yang diberi pembelajaran matematika konvensional untuk pokok bahasan yang sama.

Sedangkan untuk melihat keterlaksanaan model pembelajaran pencapaian konsep, digunakan instrumen yaitu: lembar pangamatan aktivitas guru dan siswa, angket respon siswa, lembar keterlaksanaan pencapaian pembelajaran. Hasil penelitian ini mendukung penelitian sebeluknya seperti: pemanfaatan media pembelajaran kontekstual yang tepat dan sesuai dengan kebutuhan, dapat meningkatkan kemampuan siswa dalam proses pencapaian konsep dan prinsip matematika serta 
meningkatkan ketuntasan belajar siswa; Media pembelajaran kontekstual dapat dengan efektif menghasilkan pola (pattern) yang dapat dengan mudah siswa menyusun peryataan awal (conjecture) dan dengan aktivitas matematisasi vertikal, siswa dengan bantuan teman yang lebih mampu atau guru dapat mencapai konsep dan prinsip yang sedang mereka pelajari; Lebih dari $82 \%$ siswa mampu mencapai konsep dan prinsip dengan benar; Ada 78\% siswa mampu menyusun definisi dan teorema dengan tepat; Rerata tingkat ketuntasan belajar mencapai sebesar 86,5\%; Ditemukan $14 \%$ peserta didik yang mampu meningkat sejauh tiga level perkembangan kognitif (dari Level Intra meningkat ke Level Semi-trans dalam Pelevelan Extended Triad-Level++) (Wahyu Widada, 2015)(Wahyu Widada, 2004). Juga, mathematical understanding of students who learned the ethnomathematics oriented materials was lower compared to the students learned the nonethnomathematics materials (W. Widada, Herawaty, \& Lubis, 2018).

\section{Simpulan dan Saran}

Berdasarkan hasil penelitian yang telah dikemukakan, dapat disimpulkan bahwa:

1) Ada pengaruh model pembelajaran pencapaian konsep terhadap kemampuan bertanya siswa kelas VII SMP Negeri 2 Pondok Kubang.

2) Ada pengaruh model pembelajaran pencapaian konsep terhadap kemampuan pemahaman konsep siswa kelas VII SMP Negeri 2 Pondok Kubang.

3) Kemampuan bertanya siswa kelas VII SMP Negeri 2 Pondok Kubang.yang diajarkan dengan model pembelajaran pencapaian konsep lebih tinggi dari siswa yang diajarkan dengan pembelajaran konvensional. Kemampuan bertanya siswa yang diajarkan dengan pembelajaran pencapaian konsep, yaitu siswa yang tuntas 42 dari 45 orang dan persentase ketuntasan klasikal 93\%. Sedangakan siswa yang diajarkan dengan pembelajaran konvensional,yaitu siswa yang tuntas 3 dari 45 orang dan persentase ketuntasan klasikal sebesar 6,67\%.

4) Kemampuan pemahaman konsep siswa kelas VII SMP Negeri 2 Pondok Kubang. yang diajarkan dengan model pembelajaran pencapaian konsep lebih tinggi dari siswa yang diajarkan dengan pembelajaran konvensional. Kemampuan pemahamam konsep siswa yang diajarkan dengan pembelajaran pencapaian konsep, yaitu siswa yang tuntas 45 orang dan persentase ketuntasan kalsikal sebesar 100\%. Sedangkan siswa yang diajarkan dengan pembelajaran konvensional, yaitu siswa yang tuntas 5 dari 45 orang dan persentase ketuntasan klasikal sebesar $11,11 \%$.

Berdasarkan analisis data yang dilakukan dan kesimpulan diatas,maka saran yang dapat peneliti kemukakan adalah:

1) Untuk mencapai kemampuan bertanya dan kemampuan pemahaman konsep matematika secara optimal dalam pembelajaran matematika VII SMP Negeri 2 Pondok Kubang., disarankan agar model Pembelajaran Pencapian Konsep dipilih sebagai alternatif fasilitas belajar. Dalam model Pembelajran Pencapaian Konsep perangkat pembelajaran seperti, LAS mutlak diperlukan selain buku penunjang lainnya.

2) Model Pembelajaran Pencapaian Konsep agar diimplementasikan dalam wujud teks matematika. Dari segi isi, teks diorientasikan dengan memperhatikan kemampuan awal siswa, dan diorientasikan sebagai media yang mudah dipahami, 
penyedia informasi baru yang bermnfaat dan berkaitan dengan strategi berpikir, penyedia penjelasan-penjelasan yang dapat membantu siswa memahami konsep yang dipelajari.

3) Penelitian ini masih sangat terbatas hanya pada kemampuan matematika ranah kognitif. Oleh karena itu, perlu penelitian lanjutan terhadap implementasi model pembelajaran pencapaian konsep pada kemampuan matematika ranah yang lain, misalnya afektif dan psikomotor.

\section{Daftar Pustaka}

Egen, Paul D \& Kauchak Donal. 1996. Stratregi for Teacher Teaching Content And Thinking Skills Third Edition. Boston Allin \& Bocon.

Masykur Ag, Moch dan Abdul Halim Fathani. 2007. Mathematical Intelligence. Jogjakarta: Ar-Ruzz Media.

Widada, W., Herawaty, D., \& Lubis, A. N. M. T. (2018). Realistic mathematics learning based on the ethnomathematics in Bengkulu to improve students' cognitive level.

Journal of Physics: Conference Series, 1088. https://doi.org/10.1088/17426596/1088/1/012028

Widada, Wahyu. (2004). Pendekatan Pembelajaran Matematika Berbasis Masalah. Surabays: Unipa Press.

Widada, Wahyu. (2015). Proses Pencapaian Konsep Matematika dengan Memanfaatkan Media Pembelajaran Kontekstual. Jurnal Penelitian Pendidikan Matematika Dan Sains, 22(1), 31-44. Retrieved from https://id.wikipedia.org/wiki/Pembelajaran 